\title{
Juicing alters oxalates contents in commonly consumed leafy vegetables in South West Nigeria
}

\author{
Temitope K. Odufuwa ${ }^{1}$, Adeleke K. Atunnise ${ }^{1}$, Olumide David Olukanni' ${ }^{2}$, \\ Bamidele Adewale Salau, ${ }^{2}$, \\ ${ }^{1}$ Department of Biochemistry, Faculty of Basic Medical Sciences Obafemi Awolowo, College of Health Sciences Olabisi Onabanjo, \\ University Ogun State Nigeria \\ ${ }^{2}$ Department of Chemical Sciences, College of Natural Sciences, Redeemer's University, Km. 46 Lagos/Ibadan Expressway, Redemption \\ City, Mowe, Ogun state, Nigeria
}

Email address:

delesalau@gmail.com (B. A. Salau)

\section{To cite this article:}

Temitope K. Odufuwa, Adeleke K. Atunnise, Olumide David Olukanni, Bamidele Adewale Salau. Juicing Alters Oxalates Contents in Commonly Consumed Leafy Vegetables in South West Nigeria. International Journal of Nutrition and Food Sciences.

Vol. 3, No. 3, 2014, pp. 183-186. doi: 10.11648/j.ijnfs.20140303.18

\begin{abstract}
Oxalic acid is present in most vegetables in varying quantity; its salts are formed as insoluble complexes at physiological $\mathrm{pH}$ with divalent cations, minerals and trace elements. The crystals of oxalates are associated with different pathological conditions including kidney stones. Sixteen vegetables obtained from four major markets in South West Nigeria were thoroughly mixed, grouped into two samples (fresh vegetables and juice extract) and four replicates for each sample were analysed. Oxalates content was analysed using standard laboratory methods. Oxalates content in fresh vegetables group vary; Amaranthus viridis has the highest and it is significantly $(\mathrm{p}<0.05)$ higher than others while Crassocephalum rubens has the least though, not significantly $(\mathrm{p}>0.05)$ different from Basella rubra, Amygdalina vernonia and Piper guineesis. Effect of juicing was notably significant in most of the vegetable when compared with their corresponding fresh vegetables. Telfairia occidentalis juice extracts had significantly $(\mathrm{p}<0.05)$ higher amount of oxalates than other juice samples, Crassocephalum rubens displayed the highest percentage increase compared with the corresponding fresh vegetable followed by Manihot esculenta while decrease was observed in three out the sixteen of the vegetables investigated and the highest percentage decrease was recorded in Talinum triangulare. The increased oxalate content observed in most of the vegetables analysed suggests the probable complications that may be associated with intake of certain vegetable juice. Hence, juicing must be used with caution. Thus, intake of such juice must be done with caution in people susceptible to oxalates intoxication.
\end{abstract}

Keywords: Juicing, Oxalates, Vegetable, Processing

\section{Introduction}

Consumption of sufficient fruits and vegetables are required for maintaining good health especially for the supply of vitamins, minerals and phytochemicals [1]. Nonetheless, they also contain antinutrients which include phytic acid, oxalic and lectins, phenolic compounds like tannins and saponins, enzyme inhibitors such as cyanogenic glycosides and glucosinolates [2] responsible for reduction in availability of certain nutrients and impairment of growth [3]. Though, the primary function of these antinutrients is to exhibit protective effects against external agents such as infection by microorganisms, environmental toxicity and predation [4], however, they can extend their adverse effect to human physiological status [5]. While phytic acid binds with some essential elements like $\mathrm{Fe}, \mathrm{Ca}, \mathrm{Zn}$ and $\mathrm{P}$ to form insoluble salts, oxalate reacts with calcium to precipitate calcium oxalate and prevent the absorption and utilization of calcium which in turn causes calcium imbalance, rickets and osteomalacia [6]. Oxalates are found in many plant products including nuts, fruits, vegetables, grains, and legumes. Oxalate crystals may induce renal problems such as renal stones by precipitate around renal tubules [5]. Physiologically high oxalate may raise the risk of urinary stones by sequestering calcium which is one of the essential ions required for osmoregulation $[6,7]$. In addition, sharp crystals of oxalate have been reported to cause injury to body tissue and also induce inflammation [7]. Iron oxalate crystals 
react with body fluids by impairing red blood cell formation as well as trapping heavy metals in the body tissues thereby causes significant oxidative stress [8]. Ingestion of not properly prepared high oxalate containing leafy vegetables however brings about severe swelling of the mouth and gut [9]. Skin contact with plants rich in oxalate produces irritations [10] where a specialized cell on the leaf surface contains a needle-shaped crystal. Hence, as irritants to humans [11] with formidable appearance, oxalate in plants have been documented to be physical deterrents to herbivore feeding $[5,12]$.

Even though, ample documentation on the toxicity of oxalates in man and other animals have been established. Yet, the levels of changes in oxalates contents in vegetable juice extracts are poorly studied. Juicing is one of the methods of processing in South Western Nigeria that is mainly adopted in the process of increasing availability of beneficial plants components like vitamins, minerals and other antioxidants at the same time the process may concentrate anti-nutrient of which oxalates is included. Therefore, this work is poised to investigate the effect of juicing on oxalate content in green leafy vegetables commonly consumed in South West Nigeria.

\section{Materials and Methods}

\subsection{Samples Collection}

Vegetables used for this research work were sourced from major markets in Ago-iwoye, Ikenne and sagamu, in Ogun state and Ketu in Lagos state, Nigeria. The weight of the samples ranged between 1 to $5 \mathrm{~kg}$; identified at the herbarium of the plant science department, Olabisi Onabanjo University.

\subsection{Samples Preparation}

The vegetables were destalked to remove the inedible parts afterwards samples of each specimen from the markets were mixed together and divided into four replicates. Each was further grouped into subgroups (Fresh and juice).

\subsubsection{Juicing}

This was done by using master chef juice extractor (model no: mc-J2101). The juice was collected.

\subsection{Determination of Oxalate}

According to the method of AOAC 1999 oxalate was determined; $0.1 \mathrm{~g}$ of sample was weighed and mixed with $30 \mathrm{ml}$ of $1 \mathrm{M} \mathrm{HCl}$. Each mixture was then shaken in a water bath at $100{ }^{\circ} \mathrm{C}$ for $30 \mathrm{~min}$. To each mixture was added $0.5 \mathrm{ml}$ of $5 \%$ calcium chloride and thoroughly mixed to precipitate out the calcium oxalate. The suspension was centrifuged at $3000 \mathrm{rpm}$ for $15 \mathrm{mins}$ and the supernatant separated. The pellet was washed twice with $2 \mathrm{ml}$ of $0.35 \mathrm{M} \mathrm{NH} \mathrm{NH}_{4} \mathrm{OH}$ then dissolved in $0.5 \mathrm{M} \mathrm{H}{ }_{2} \mathrm{SO}_{4}$. The solution was titrated with standard solution of $0.1 \mathrm{M} \mathrm{KM}$ $\mathrm{NO}_{4}$ with the temperature being maintained at $60^{\circ} \mathrm{C}$ to a faint violet colour that persisted for at least 15 seconds; which is equivalent to $2.2 \mathrm{mg}$ of oxalate [13].

\subsection{Moisture Content}

The moisture content was determined by taking $10 \mathrm{~g}$ of each sample from each replicate into a $200 \mathrm{ml}$ crucible and then samples were dried in oven at a temperature of $105^{\circ} \mathrm{C}$ for 24hour.

\subsection{Statistical Analysis}

Data were analysed by one-way analysis of variance (ANOVA), using Statistical Package for Social Sciences (SPSS) software for windows. $\mathrm{p}<0.05$ was considered significant.

\section{Results}

Table 1. Changes in oxalate content during juicing of fresh vegetables (Decrease in oxalates content)

\begin{tabular}{lllll}
\hline Botanical name & Local/ English name & $\begin{array}{l}\text { Oxalate in fresh } \\
\text { (mg/100g dry wt.) }\end{array}$ & $\begin{array}{l}\text { Oxalate in Juice } \\
\text { (mg/100g dry wt.) }\end{array}$ & $\begin{array}{l}\text { Change in oxalate content } \\
\text { (\%) decrease) }\end{array}$ \\
\hline Amaranthus spp. & Joy weed/ Ebiden & $122.45 \pm 1.99 \mathrm{a}$ & $26.05 \pm 3.26 \mathrm{a}$ & $(78.73)$ \\
Amaranthus viridis & Amaranth / Tete funfun & $591.77 \pm 9.79 \mathrm{c}$ & $153.85 \pm 0.00 \mathrm{c}$, & $(74.00)$ \\
Talinum triangulare & Water leaf / Gbure & $270.14 \pm 7.86 \mathrm{~b}$ & $101.33 \pm 5.56 \mathrm{~b}$ & $(62.49)$ \\
\hline
\end{tabular}

Results presented are mean $\pm \operatorname{SEM}(n=4)$; values in the same column with the same superscript are not significantly

different from each other $(\mathrm{P}>0.05)$. Values in brackets are negatives.

Table 2. Change in oxalate content during juicing of fresh vegetables (Increase in oxalates content below 500\%)

\begin{tabular}{|c|c|c|c|c|}
\hline Botanical name & Local/ English name & $\begin{array}{l}\text { Oxalate in fresh }(\mathrm{mg} / 100 \mathrm{~g} \\
\text { dry wt.) }\end{array}$ & $\begin{array}{l}\text { Oxalate in Juice } \\
\text { (mg/100g dry wt.) }\end{array}$ & $\begin{array}{l}\text { Change in oxalate content } \\
\text { (\% increase) }\end{array}$ \\
\hline Ipomoea batatas & Sweet potatoes leaf / Ewe odukun & $63.77 \pm 1.94 \mathrm{c}$ & $377.56 \pm 23.95 \mathrm{c}$ & 492.07 \\
\hline Solanecio biafrae & Oliv. and Hiern / Woorowo & $77.84 \pm 0.73 d$ & $262.91 \pm 12.96 b$ & 237.76 \\
\hline Colocasia esculenta & Cocoyam leaf/ ewe koko & $68.21 \pm 4.47 \mathrm{c}, \mathrm{d}$ & $141.23 \pm 4.06 \mathrm{a}$ & 107.05 \\
\hline Corchorus oliterus & Jute plant / Ewedu & $46.22 \pm 0.90 \mathrm{~b}$ & $126.59 \pm 7.39 \mathrm{a}$ & 173.89 \\
\hline Celosia argentea & Soko pupa / Cockscomb & $75.00 \pm 3.57 \mathrm{c}, \mathrm{d}$ & $411.29 \pm 9.01 \mathrm{c}$ & 448.39 \\
\hline Basella rubra & Indian Spinach / Amunututu pupa & $20.16 \pm 0.78 \mathrm{a}$ & $120.39 \pm 3.69 \mathrm{a}$ & 497.17 \\
\hline Basella alba & Malabar Spinach / Amunututu & $294.12 \pm 0.00 \mathrm{e}$ & $384.05 \pm 31.30 \mathrm{c}$ & 30.58 \\
\hline
\end{tabular}


Results presented are mean $\pm \operatorname{SEM}(n=4)$; values in the same column with the same superscript are not significantly

different from each other $(\mathrm{P}>0.05)$.

Table 3. Change in oxalate content during juicing of fresh vegetables (Increase in oxalates content above 500\%)

\begin{tabular}{lllll}
\hline Botanical name & Local/ English name & $\begin{array}{l}\text { Oxalate in fresh } \\
\text { (mg/100g dry wt.) }\end{array}$ & $\begin{array}{l}\text { Oxalate in Juice } \\
\text { (mg/100g dry wt.) }\end{array}$ & $\begin{array}{l}\text { Change in oxalate content } \\
\text { (\% increase) }\end{array}$ \\
\hline Crassocephalum rubens & Ebolo & $19.43 \pm 0.32 \mathrm{a}$ & $382.37 \pm 29.60 \mathrm{~d}$ & 1867.94 \\
Manihot esculenta & Cassava leaf/ Ewe paki & $34.26 \pm 2.83 \mathrm{~b}$ & $558.90 \pm 15.98 \mathrm{e}$ & 1531.35 \\
Telfairia occidentalis & fluted pumpkin leaf/ Ugwu & $152.41 \pm 7.21 \mathrm{c}$ & $1170.92 \pm 28.06 \mathrm{f}$ & 668.27 \\
Piper guineesis & Uziza & $30.90 \pm 2.14 \mathrm{a}, \mathrm{b}$ & $196.50 \pm 17.81 \mathrm{a}$ & 535.92 \\
Launaea taraxacifolia & Wild Lettuce / Yanrin & $39.35 \pm 1.24 \mathrm{~b}$ & $327.45 \pm 6.36 \mathrm{c}$ & 732.15 \\
Amygdalina veronia & Bitter leaf / Ewuro & $20.70 \pm 4.14 \mathrm{a}$ & $262.50 \pm 12.50 \mathrm{~b}$ & 1168.12 \\
\hline
\end{tabular}

Results presented are mean $\pm \operatorname{SEM}(n=4)$; values in the same column with the same superscript are not significantly different from each other $(\mathrm{P}>0.05)$.

Table 1 above showed vegetables with decrease of oxalate content in juice extracts when compared with fresh vegetables. Amaranthus viridis has the highest oxalate content both in fresh and juice extracts and there is a significant $(p<0.05)$ difference, while Amaranthus spp. contain the least among the three vegetables and it is significantly $(p<0.05)$ lower than Talinum triangulare. Though, oxalate in Amaranthus spp. both in fresh and juice appear to be the highest, however, greatest loss of oxalate content in juice extract was noticed in it while, the least was observed in Talinum triangulare.

Table 2 presents vegetable with less than $500 \%$ increase oxalate content in juice extracts when compared with fresh vegetables. In fresh vegetables, oxalate content in Basella alba is significantly $(\mathrm{p}<0.05)$ higher than others while the least was observed in Basella rubra. Celosia argentea juice extract contain the highest with a significant difference $(p<0.05)$ except with Basella alba and Ipomoea batatas. The least increase in oxalate content was noticed in Basella alba (30.58\%) and the highest increase in Basella rubra (497\%).

Table 3 presents vegetables with $500 \%$ and above yield of oxalate content in juice extracts when compared with the fresh vegetables. Telfairia occidentalis had significantly $(p<0.05)$ higher concentration of oxalates than other fresh vegetables in this group while the least was observed in Crassocephalum rubens though not significantly different ( $p>0.05$ ) form most of the vegetables, Also, Telfairia occidentalis juice extracts has the highest oxalate content and it is significantly $(\mathrm{p}<0.05)$ different from others in this groups while Piper guinesis contain the least and it is significantly $(\mathrm{p}<0.05)$ lower. Crassocephalum rubens juice extract presents the highest increase in oxalates contain $(1867.94 \%)$ while, Piper guineesis gained the least oxalate $(535.92 \%)$ in this group.

\section{Discussion}

The distribution and form in which oxalates are present in plants tissues are associated to many factors such as nutrient demand, hydrogen ion concentration, soil and environmental toxicity, osmotic pressure [14] as well as predation. Effect of juicing on oxalates content in leafy vegetables varies among different plant species; it increases oxalate content to about $500 \%$ in many and decrease to about $80 \%$ in a few. The significantly $(\mathrm{p}<0.05)$ high oxalate content in fresh Amaranthus viridis, Basella alba, Talinum triangulare, Ipomoea batatas and Amaranthus spp. observed could be attributed to the broad variations hitherto aforementioned. Olumuyiwa et. al. (2004) [15], reported close values of oxalates in Amaranthus viridis and Basella alba as observed in this study.

Furthermore, plants tissue matrix are determinants in crystals formation of calcium oxalate [16], this is because most of the enzymes that catalyze the process are matrix bound [17]. Also ascorbic acid degradation is reported to lead to oxalates formation in Amaranthus [18]. Poor transpiration as well as rapidly proliferation in plants tissue may reversibly dissociate calcium oxalate to mobilize calcium for structural stability [19] hence, contributes to reduced oxalates content noted in Crassocephalum rubens, Amygdalina vernonia, Basella rubra and Piper guineesis. Similarly, Akindahunsi (2005) reported similar low oxalate content in these vegetables [20]. With the exception of Amaranthus spp, Amaranthus, viridis and Talinum triangulare, juicing significantly increase oxalates contents in the juice extract of most of the vegetables investigated. This could be ascribed to the resultant effect of mechanical force of juicing stimulating oxalates formation as a defensive mechanism [21] in plants. Thus, taking vegetable juice of those vegetables with high content of oxalates in their juice may make one prone to problems associated with oxalate toxicity such as kidney stone [5], chelation of essential minerals [7] and generation of free radicals [8].

\section{Conclusion}

This study revealed that juicing increase oxalate content in most leafy vegetables commonly consumed in South West Nigeria. High concentration of oxalates were observed in Crassocephalum rubens, Manihot esculenta, Telfairia occidentalis, Piper guineesis, Launaea taraxacifolia and Amygdalina Vernonia and as such juice of those vegetable should be consumed with caution because of problems associated with oxalate consumption, which include renal stones, impairment of red blood cells and oxidative stress; a scaffold for diseases such as cancer, atherosclerosis and 
diabetes. Thus, intake of juice of oxalates rich vegetable should be avoided by subject with history of renal disorders, pregnant women and growing children.

Though, oxalate reduced in of juices of Amaranthus spp, Amaranthus viridis and Talinum Triangulare, hence these vegetable juices could be consumed at a moderate level.

\section{Acknowledgement}

We acknowledge college of Natural sciences, Redeemers University for granting the laboratory space for this work, also special thanks to Professor G. A. Kolawole the former Head of Department of chemical sciences for his moral support.

\section{References}

[1] World Health Organization. WHO Fruit and Vegetable Promotion Initiative - report of the meeting. Geneva: World Health Organization 2003.

[2] L. K. Massey, R. G. Palmer, H. T. Horner (2001). Oxalate content of soybean seeds (Glycine max: Leguminosae), soyfoods, and other edible legumes. J Agric Food Chem. 49(9):4262-6.

[3] R. M. Citation, R. M. Alcantara, W. A. Hurtada, E. I. Dizon (2013) The Nutritional Value and Phytochemical Components of Taro [Colocasia esculenta (L.) Schott] Powder and its Selected Processed Foods. J Nutr Food Sci 3: 207.

[4] A. Musa, E. O. Ogbadoyi (2012) Effect of Cooking and Sun Drying On Micronutrients, Antinutrients and Toxic Substances in Corchorus olitorius (Jute Mallow). J Nutr Food Sci 2:14.

[5] R. Selvam andP. Kalaiselvi (2001). Studies on Calcium Oxalate Binding Proteins: Effect of Lipid Peroxidation. Nephron88:163-167.

[6] F. Shahidi, (1997). Antinutrients and Phytochemicals in Food;ACS Symposium Series; American Chemical Society: Washington, DC.

[7] M. A. Ahmed Mazen, Dianzhong Zhang and R. Vincent Franceschi, (2003). Calcium oxalate formation in Lemna minor: physiological and ultrastructural aspects of high capacity calcium sequestration New Phytologist 161: 435448

[8] A. J. Ghio, V. L. Roggli, T. P. Kennedy, C. A. Piantadosi (2000). Calcium oxalate and iron accumulation in sarcoidosis. Sarcoidosis Vasc Diffuse Lung Dis 17(2):140-50.

[9] L. Kenneth Korth, J. Sarah Doege, Sang-Hyuck Park, L. Fiona Goggin, Qin Wang, S. Karen Gomez, Guangjie Liu, Lingling Jia, and A. Paul Nakata (2006). Medicago truncatula Mutants Demonstrate the Role of Plant Calcium
Oxalate Crystals as an Effective Defense against Chewing Insects. Plant Physiology 141: 188-195.

[10] E. L. Thurston (1976) Morphology, fine structure and ontogeny of the stinging emergence of Tragia ramosa and $\mathrm{T}$. saxicola (Euphorbiaceae). Am J Bot 63: 710-718.

[11] M. L. Salinas, T. Ogura andL. Soffchi (2001). Irritant contact dermatitis caused by needle-like calcium oxalate crystals, raphides, in Agave tequilana among workers in tequila distilleries and agave plantations. Contact Dermatitis 44: 94-96.

[12] R. H. Whittaker (1970). The biochemical ecology of higher plants. In E Sondheimer, JB Simeone, eds, Chemical Ecology. Academic Press, London; 43-102.

[13] AOAC. (1999). Association of Official Analytical Chemists, Official Methods of Analysis. Washington DC. Baker, C. J. L. (1952). The determination of oxalates in fresh plant material. Analyst, 77, 340

[14] G. Ayala-Cordero, T. Terrazas, L. López-Mata andC. Trejo (2006). Morpho-anatomical changes and photosynthetic metabolism of Stenocereus beneckei seedlings under soil water deficit. J Exp Bot. 57(12): 3165-74.

[15] S. Oluwamuyi Falade, A. F. Dare, O. Muibat Bello, O. Bolanle Osuntogun and R. A. Steve Adewusi (2004). Varietal Change in Proximate Composition and Effecf of Processing on the Ascorbic Acid Content of Some Nigerian Vegetables. Journal of Food Technology 2(2): $103-108$.

[16] G. M. Volk, V. M. Lynch-Holm, T. A. Kostman, L. Goss, V. R. Franceschi (2002). The role of druse and raphide calcium oxalate crystals in tissue calcium regulation in Pistia stratiotes leaves. Plant Biology 4: 34-45.

[17] N. Bouropoulos, S. Weiner and L. Addadi (2001) Calcium oxalate crystals in tomato and tobacco plants: morphology and in vitro interactions of crystal-associated macromolecules. Chemistry (Easton) 7: 1881-1888.

[18] P.S. Negi and S. K. Roy (2003). Changes in beta-carotene and ascorbic acid content of fresh amaranth and fenugreek leaves during storage by low cost technique. Plant Foods Hum Nutr.;58(3):225-230.

[19] J. Calmes and J. Carles (1970). Le repartition et líevolution des cristaux díoxalate de calcium dans les tissues de Vigne vierge au cours díun cycle de vegetation. Bulletin de la Societe Botanique de France 117: 189-198.

[20] A A Akindahunsi, S O Salawu (2005). Phytochemical screening and nutrient-antinutrient composition of selected tropical green leafy vegetables; African Journal of Biotechnology. 4; 6 .

[21] B. Molano-Flores (2001). Herbivory and calcium concentrations affect calcium oxalate crystal formation in leaves of Sida (Malvaceae). Ann Bot (Lond) 88: 387-391.

[22] M. A. Webb (1999) Cell-mediated crystallization of calcium oxalate in plants. Plant Cell 11: 751-761. 